ICMJE DISCLOSURE FORM

Date: $3 / 29 / 2021$

Your Name:__ Alyssa Gould

Manuscript Title: Less Common Bacterial, Fungal, and Viral Infections: Review of Management in the Pregnant Patient

Manuscript number (if known):

In the interest of transparency, we ask you to disclose all relationships/activities/interests listed below that are related to the content of your manuscript. "Related" means any relation with for-profit or not-for-profit third parties whose interests may be affected by the content of the manuscript. Disclosure represents a commitment to transparency and does not necessarily indicate a bias. If you are in doubt about whether to list a relationship/activity/interest, it is preferable that you do so.

The following questions apply to the author's relationships/activities/interests as they relate to the current manuscript only.

The author's relationships/activities/interests should be defined broadly. For example, if your manuscript pertains to the epidemiology of hypertension, you should declare all relationships with manufacturers of antihypertensive medication, even if that medication is not mentioned in the manuscript.

In item \#1 below, report all support for the work reported in this manuscript without time limit. For all other items, the time frame for disclosure is the past $\mathbf{3 6}$ months.

\begin{tabular}{|c|c|c|c|}
\hline & & $\begin{array}{l}\text { Name all entities with } \\
\text { whom you have this } \\
\text { relationship or indicate } \\
\text { none (add rows as } \\
\text { needed) }\end{array}$ & $\begin{array}{l}\text { Specifications/Comments } \\
\text { (e.g., if payments were made to you or to your } \\
\text { institution) }\end{array}$ \\
\hline & & \multicolumn{2}{|c|}{ Time frame: Since the initial planning of the work } \\
\hline \multirow[t]{6}{*}{1} & \multirow{6}{*}{$\begin{array}{l}\text { All support for the present } \\
\text { manuscript (e.g., funding, } \\
\text { provision of study materials, } \\
\text { medical writing, article } \\
\text { processing charges, etc.) } \\
\text { No time limit for this item. }\end{array}$} & _. None & \\
\hline & & & \\
\hline & & & \\
\hline & & & \\
\hline & & & \\
\hline & & & \\
\hline & & Time frame: $p$ & 36 months \\
\hline \multirow[t]{3}{*}{2} & \multirow{3}{*}{$\begin{array}{l}\text { Grants or contracts from } \\
\text { any entity (if not indicated } \\
\text { in item } \# 1 \text { above). }\end{array}$} & $x$ _None & \\
\hline & & & \\
\hline & & & \\
\hline \multirow[t]{2}{*}{3} & \multirow[t]{2}{*}{ Royalties or licenses } & _. & \\
\hline & & & \\
\hline \multirow[t]{2}{*}{4} & \multirow[t]{2}{*}{ Consulting fees } & . $\mathrm{x}$ _None & \\
\hline & & & \\
\hline
\end{tabular}




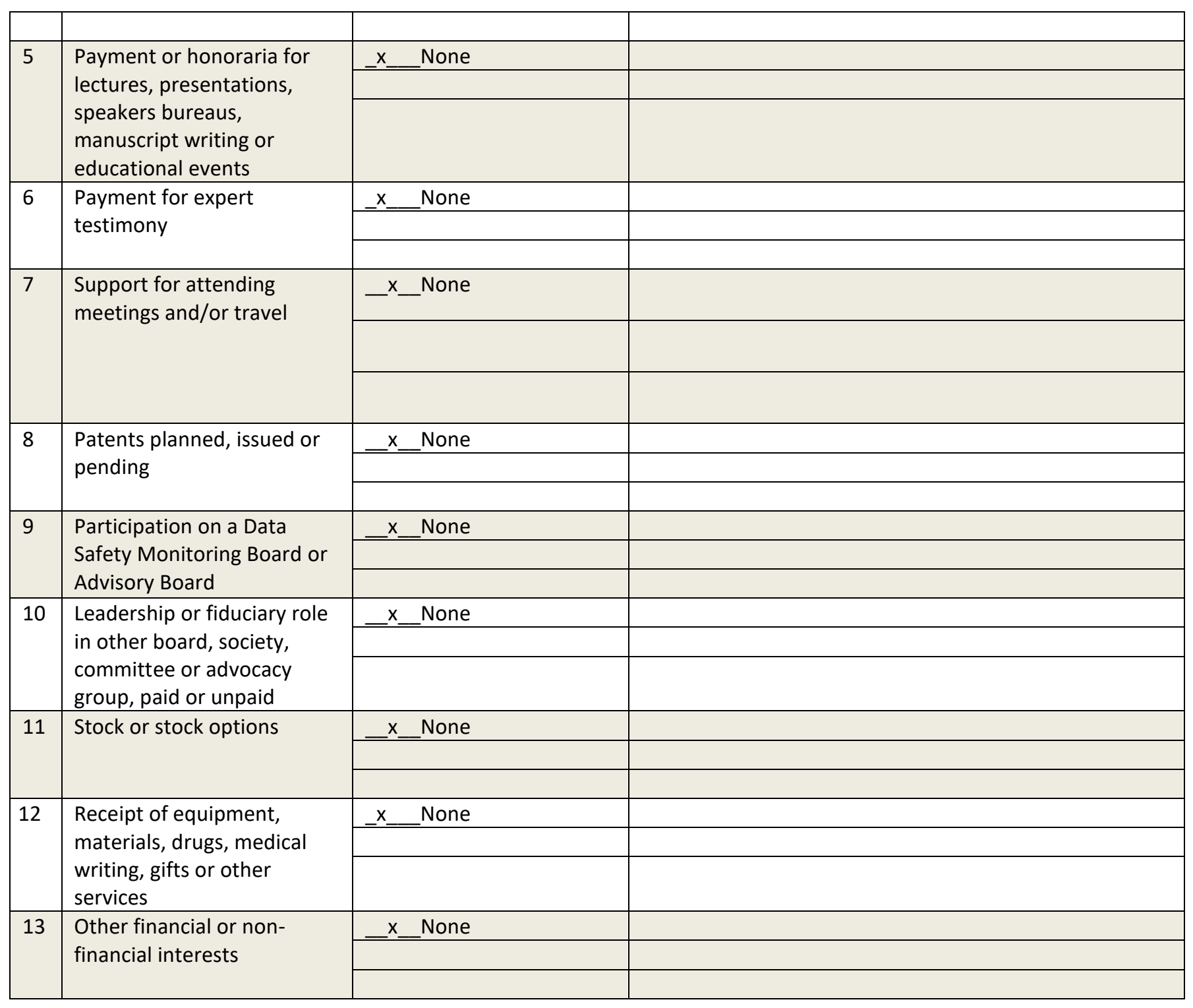

Please place an " $X$ " next to the following statement to indicate your agreement:

_ X_ I certify that I have answered every question and have not altered the wording of any of the questions on this form. 
ICMJE DISCLOSURE FORM

Date: $3 / 16 / 2021$

Your Name:

Hana R. Winders

Manuscript Title: Less Common Bacterial, Fungal, and Viral Infections: Review of Management in the Pregnant Patient

Manuscript number (if known):

In the interest of transparency, we ask you to disclose all relationships/activities/interests listed below that are related to the content of your manuscript. "Related" means any relation with for-profit or not-for-profit third parties whose interests may be affected by the content of the manuscript. Disclosure represents a commitment to transparency and does not necessarily indicate a bias. If you are in doubt about whether to list a relationship/activity/interest, it is preferable that you do so.

The following questions apply to the author's relationships/activities/interests as they relate to the current manuscript only.

The author's relationships/activities/interests should be defined broadly. For example, if your manuscript pertains to the epidemiology of hypertension, you should declare all relationships with manufacturers of antihypertensive medication, even if that medication is not mentioned in the manuscript.

In item \#1 below, report all support for the work reported in this manuscript without time limit. For all other items, the time frame for disclosure is the past $\mathbf{3 6}$ months.

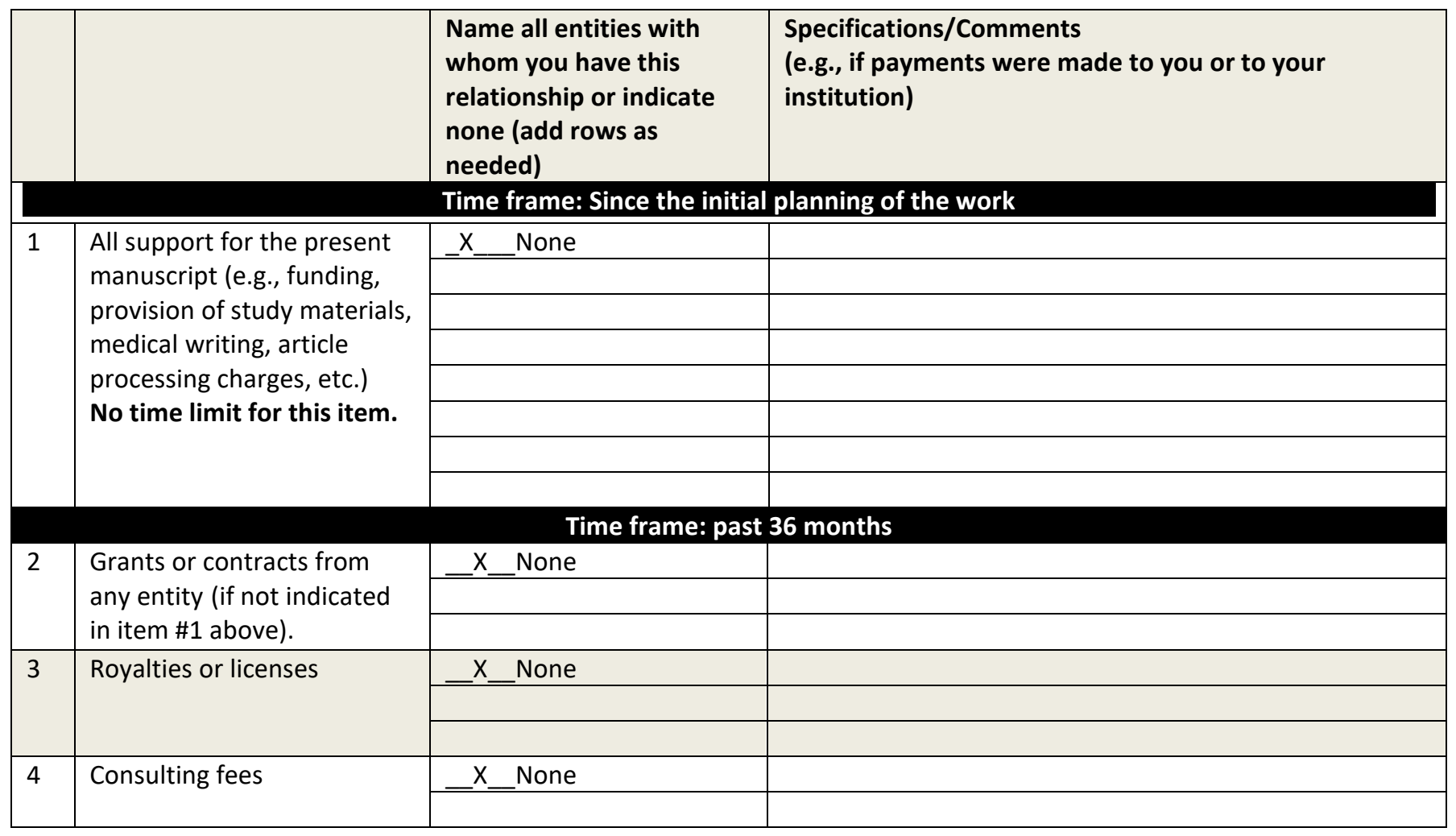




\begin{tabular}{|c|c|c|c|}
\hline \multirow[t]{2}{*}{5} & \multirow{2}{*}{$\begin{array}{l}\text { Payment or honoraria for } \\
\text { lectures, presentations, } \\
\text { speakers bureaus, } \\
\text { manuscript writing or } \\
\text { educational events }\end{array}$} & None & $\begin{array}{l}\text { Speaker's Bureau for bioMerieux (payments made to } \\
\text { me) }\end{array}$ \\
\hline & & & \\
\hline \multirow[t]{2}{*}{6} & \multirow{2}{*}{$\begin{array}{l}\text { Payment for expert } \\
\text { testimony }\end{array}$} & X_None & \\
\hline & & & \\
\hline \multirow[t]{2}{*}{7} & \multirow[t]{2}{*}{$\begin{array}{l}\text { Support for attending } \\
\text { meetings and/or travel }\end{array}$} & - $\ldots$ _None & \\
\hline & & & \\
\hline \multirow[t]{2}{*}{8} & \multirow{2}{*}{$\begin{array}{l}\text { Patents planned, issued or } \\
\text { pending }\end{array}$} & _ & \\
\hline & & & \\
\hline \multirow[t]{2}{*}{9} & \multirow{2}{*}{$\begin{array}{l}\text { Participation on a Data } \\
\text { Safety Monitoring Board or } \\
\text { Advisory Board }\end{array}$} & $x$ _ None & \\
\hline & & & \\
\hline \multirow[t]{3}{*}{10} & \multirow{3}{*}{$\begin{array}{l}\text { Leadership or fiduciary role } \\
\text { in other board, society, } \\
\text { committee or advocacy } \\
\text { group, paid or unpaid }\end{array}$} & $x$ _ None & \\
\hline & & & \\
\hline & & & \\
\hline \multirow[t]{2}{*}{11} & \multirow[t]{2}{*}{ Stock or stock options } & _ & \\
\hline & & & \\
\hline \multirow[t]{3}{*}{12} & \multirow{3}{*}{$\begin{array}{l}\text { Receipt of equipment, } \\
\text { materials, drugs, medical } \\
\text { writing, gifts or other } \\
\text { services }\end{array}$} & X__ None & \\
\hline & & & \\
\hline & & & \\
\hline \multirow[t]{2}{*}{13} & \multirow{2}{*}{$\begin{array}{l}\text { Other financial or non- } \\
\text { financial interests }\end{array}$} & _. None & \\
\hline & & & \\
\hline
\end{tabular}

Please place an " $X$ " next to the following statement to indicate your agreement:

_. _ I I certify that I have answered every question and have not altered the wording of any of the questions on this form. 
ICMJE DISCLOSURE FORM

Date: $3 / 16 / 2021$

Your Name:_Kayla R. Stover

Manuscript Title: Less Common Bacterial, Fungal, and Viral Infections: Review of Management in the Pregnant

Patient

Manuscript number (if known):

In the interest of transparency, we ask you to disclose all relationships/activities/interests listed below that are related to the content of your manuscript. "Related" means any relation with for-profit or not-for-profit third parties whose interests may be affected by the content of the manuscript. Disclosure represents a commitment to transparency and does not necessarily indicate a bias. If you are in doubt about whether to list a relationship/activity/interest, it is preferable that you do so.

The following questions apply to the author's relationships/activities/interests as they relate to the current manuscript only.

The author's relationships/activities/interests should be defined broadly. For example, if your manuscript pertains to the epidemiology of hypertension, you should declare all relationships with manufacturers of antihypertensive medication, even if that medication is not mentioned in the manuscript.

In item \#1 below, report all support for the work reported in this manuscript without time limit. For all other items, the time frame for disclosure is the past $\mathbf{3 6}$ months.

\begin{tabular}{|c|c|c|c|}
\hline & & $\begin{array}{l}\text { Name all entities with } \\
\text { whom you have this } \\
\text { relationship or indicate } \\
\text { none (add rows as } \\
\text { needed) }\end{array}$ & $\begin{array}{l}\text { Specifications/Comments } \\
\text { (e.g., if payments were made to you or to your } \\
\text { institution) }\end{array}$ \\
\hline \multicolumn{4}{|c|}{ Time frame: Since the initial planning of the work } \\
\hline \multirow[t]{7}{*}{$\overline{1}$} & \multirow{7}{*}{$\begin{array}{l}\text { All support for the present } \\
\text { manuscript (e.g., funding, } \\
\text { provision of study materials, } \\
\text { medical writing, article } \\
\text { processing charges, etc.) } \\
\text { No time limit for this item. }\end{array}$} & X_None & \\
\hline & & & \\
\hline & & & \\
\hline & & & \\
\hline & & & \\
\hline & & & \\
\hline & & & \\
\hline \multirow{3}{*}{2} & & Time frame: $p$ & 36 months \\
\hline & \multirow{2}{*}{$\begin{array}{l}\text { Grants or contracts from } \\
\text { any entity (if not indicated } \\
\text { in item \#1 above). }\end{array}$} & $\mathrm{X}$ None & \\
\hline & & & \\
\hline \multirow[t]{2}{*}{3} & \multirow[t]{2}{*}{ Royalties or licenses } & X_None & \\
\hline & & & \\
\hline \multirow[t]{2}{*}{4} & \multirow[t]{2}{*}{ Consulting fees } & $\mathrm{X}$ _ None & \\
\hline & & & \\
\hline
\end{tabular}




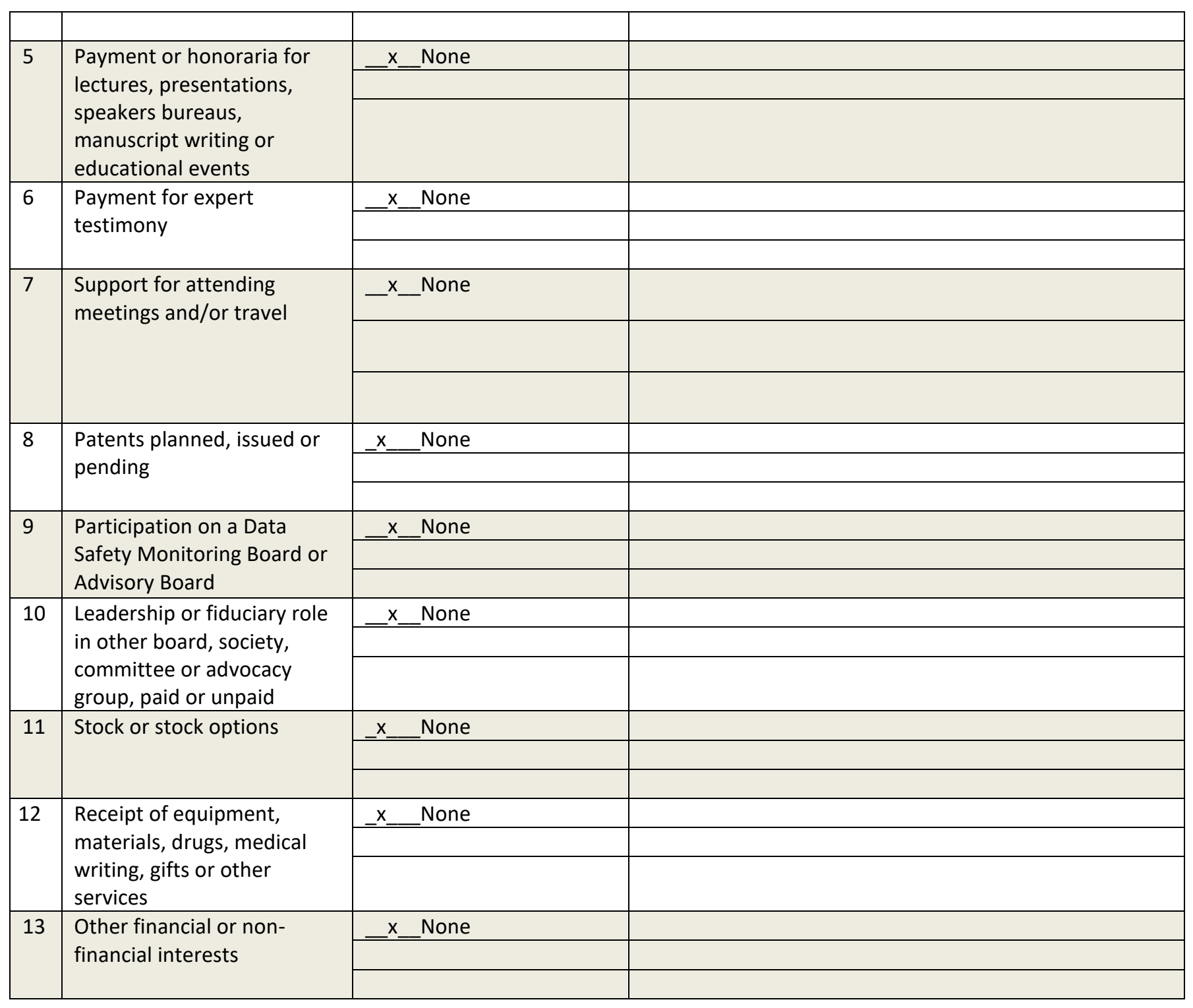

Please place an " $X$ " next to the following statement to indicate your agreement:

_ form. 
ICMJE DISCLOSURE FORM

Date:_3/8/2021

Your Name:

P. Brandon Bookstaver

Manuscript Title: Less Common Bacterial, Fungal, and Viral Infections: Review of Management in the Pregnant Patient

Manuscript number (if known):

In the interest of transparency, we ask you to disclose all relationships/activities/interests listed below that are related to the content of your manuscript. "Related" means any relation with for-profit or not-for-profit third parties whose interests may be affected by the content of the manuscript. Disclosure represents a commitment to transparency and does not necessarily indicate a bias. If you are in doubt about whether to list a relationship/activity/interest, it is preferable that you do so.

The following questions apply to the author's relationships/activities/interests as they relate to the current manuscript only.

The author's relationships/activities/interests should be defined broadly. For example, if your manuscript pertains to the epidemiology of hypertension, you should declare all relationships with manufacturers of antihypertensive medication, even if that medication is not mentioned in the manuscript.

In item \#1 below, report all support for the work reported in this manuscript without time limit. For all other items, the time frame for disclosure is the past 36 months.

\begin{tabular}{|c|c|c|c|}
\hline & & $\begin{array}{l}\text { Name all entities with } \\
\text { whom you have this } \\
\text { relationship or indicate } \\
\text { none (add rows as } \\
\text { needed) }\end{array}$ & $\begin{array}{l}\text { Specifications/Comments } \\
\text { (e.g., if payments were made to you or to your } \\
\text { institution) }\end{array}$ \\
\hline & & \multicolumn{2}{|c|}{ Time frame: Since the initial planning of the work } \\
\hline \multirow[t]{6}{*}{1} & \multirow{6}{*}{$\begin{array}{l}\text { All support for the present } \\
\text { manuscript (e.g., funding, } \\
\text { provision of study materials, } \\
\text { medical writing, article } \\
\text { processing charges, etc.) } \\
\text { No time limit for this item. }\end{array}$} & _. None & \\
\hline & & & \\
\hline & & & \\
\hline & & & \\
\hline & & & \\
\hline & & & \\
\hline & & Time frame: $p$ & 36 months \\
\hline \multirow[t]{2}{*}{2} & \multirow{2}{*}{$\begin{array}{l}\text { Grants or contracts from } \\
\text { any entity (if not indicated } \\
\text { in item \#1 above). }\end{array}$} & None & \\
\hline & & ALK Abello & $\begin{array}{l}\text { Payments to institution; work related to penicillin allergy } \\
\text { skin testing }\end{array}$ \\
\hline 3 & Royalties or licenses & $\mathrm{x}$ _None & \\
\hline 4 & Consulting fees & None & \\
\hline
\end{tabular}




\begin{tabular}{|c|c|c|c|}
\hline & & Kedrion BioPharma & Research advisory committee; money paid to me \\
\hline \multirow[t]{3}{*}{5} & \multirow{3}{*}{$\begin{array}{l}\text { Payment or honoraria for } \\
\text { lectures, presentations, } \\
\text { speakers bureaus, } \\
\text { manuscript writing or } \\
\text { educational events }\end{array}$} & None & \\
\hline & & FreeCE.com & $\begin{array}{l}\text { Paid to me for C. difficile infection program development } \\
\text { and speaking }\end{array}$ \\
\hline & & TRC Healthcare & $\begin{array}{l}\text { Paid to me for stewardship related module development } \\
\text { and speaking }\end{array}$ \\
\hline \multirow[t]{2}{*}{6} & \multirow{2}{*}{$\begin{array}{l}\text { Payment for expert } \\
\text { testimony }\end{array}$} & _ & \\
\hline & & & \\
\hline \multirow[t]{2}{*}{7} & \multirow{2}{*}{$\begin{array}{l}\text { Support for attending } \\
\text { meetings and/or travel }\end{array}$} & None & \\
\hline & & Kedrion BioPharma & $\begin{array}{l}\text { Attending an advisory board meeting, travel to } 1 \\
\text { meeting }\end{array}$ \\
\hline \multirow[t]{2}{*}{8} & \multirow{2}{*}{$\begin{array}{l}\text { Patents planned, issued or } \\
\text { pending }\end{array}$} & x_None & \\
\hline & & & \\
\hline \multirow[t]{2}{*}{9} & \multirow{2}{*}{$\begin{array}{l}\text { Participation on a Data } \\
\text { Safety Monitoring Board or } \\
\text { Advisory Board }\end{array}$} & $x$ _ None & \\
\hline & & & \\
\hline \multirow[t]{3}{*}{10} & \multirow{3}{*}{$\begin{array}{l}\text { Leadership or fiduciary role } \\
\text { in other board, society, } \\
\text { committee or advocacy } \\
\text { group, paid or unpaid }\end{array}$} & None & \\
\hline & & $\begin{array}{l}\text { American College of } \\
\text { Clinical Pharmacy }\end{array}$ & Board of Regents, no money received \\
\hline & & & \\
\hline \multirow[t]{2}{*}{11} & \multirow[t]{2}{*}{ Stock or stock options } & $\mathrm{x}$ _None & \\
\hline & & & \\
\hline \multirow[t]{3}{*}{12} & \multirow{3}{*}{$\begin{array}{l}\text { Receipt of equipment, } \\
\text { materials, drugs, medical } \\
\text { writing, gifts or other } \\
\text { services }\end{array}$} & _. None & \\
\hline & & & \\
\hline & & & \\
\hline \multirow[t]{2}{*}{13} & \multirow{2}{*}{$\begin{array}{l}\text { Other financial or non- } \\
\text { financial interests }\end{array}$} & _. None & \\
\hline & & & \\
\hline
\end{tabular}

Please place an " $X$ " next to the following statement to indicate your agreement:

____ I certify that I have answered every question and have not altered the wording of any of the questions on this form. 


\section{ICMJE DISCLOSURE FORM}

Date:_3/8/2021

Your Name:____ Brooke Griffin

Manuscript Title: Less Common Bacterial, Fungal, and Viral Infections: Review of Management in the Pregnant

Patient

Manuscript number (if known):

In the interest of transparency, we ask you to disclose all relationships/activities/interests listed below that are related to the content of your manuscript. "Related" means any relation with for-profit or not-for-profit third parties whose interests may be affected by the content of the manuscript. Disclosure represents a commitment to transparency and does not necessarily indicate a bias. If you are in doubt about whether to list a relationship/activity/interest, it is preferable that you do so.

The following questions apply to the author's relationships/activities/interests as they relate to the current manuscript only.

The author's relationships/activities/interests should be defined broadly. For example, if your manuscript pertains to the epidemiology of hypertension, you should declare all relationships with manufacturers of antihypertensive medication, even if that medication is not mentioned in the manuscript.

In item \#1 below, report all support for the work reported in this manuscript without time limit. For all other items, the time frame for disclosure is the past $\mathbf{3 6}$ months.

\begin{tabular}{|c|c|c|c|}
\hline & & $\begin{array}{l}\text { Name all entities with } \\
\text { whom you have this } \\
\text { relationship or indicate } \\
\text { none (add rows as } \\
\text { needed) }\end{array}$ & $\begin{array}{l}\text { Specifications/Comments } \\
\text { (e.g., if payments were made to you or to your } \\
\text { institution) }\end{array}$ \\
\hline \multicolumn{4}{|c|}{ Time frame: Since the initial planning of the work } \\
\hline \multirow[t]{7}{*}{1} & \multirow{7}{*}{$\begin{array}{l}\text { All support for the present } \\
\text { manuscript (e.g., funding, } \\
\text { provision of study materials, } \\
\text { medical writing, article } \\
\text { processing charges, etc.) } \\
\text { No time limit for this item. }\end{array}$} & BG_None & \\
\hline & & & \\
\hline & & & \\
\hline & & & \\
\hline & & & \\
\hline & & & \\
\hline & & & \\
\hline \multirow{3}{*}{2} & \multicolumn{3}{|c|}{ Time frame: past 36 months } \\
\hline & \multirow{2}{*}{$\begin{array}{l}\text { Grants or contracts from } \\
\text { any entity (if not indicated } \\
\text { in item \#1 above). }\end{array}$} & BG__None & \\
\hline & & & \\
\hline \multirow[t]{2}{*}{3} & \multirow[t]{2}{*}{ Royalties or licenses } & BG___None & \\
\hline & & & \\
\hline \multirow[t]{2}{*}{4} & \multirow[t]{2}{*}{ Consulting fees } & BG_None & \\
\hline & & & \\
\hline
\end{tabular}




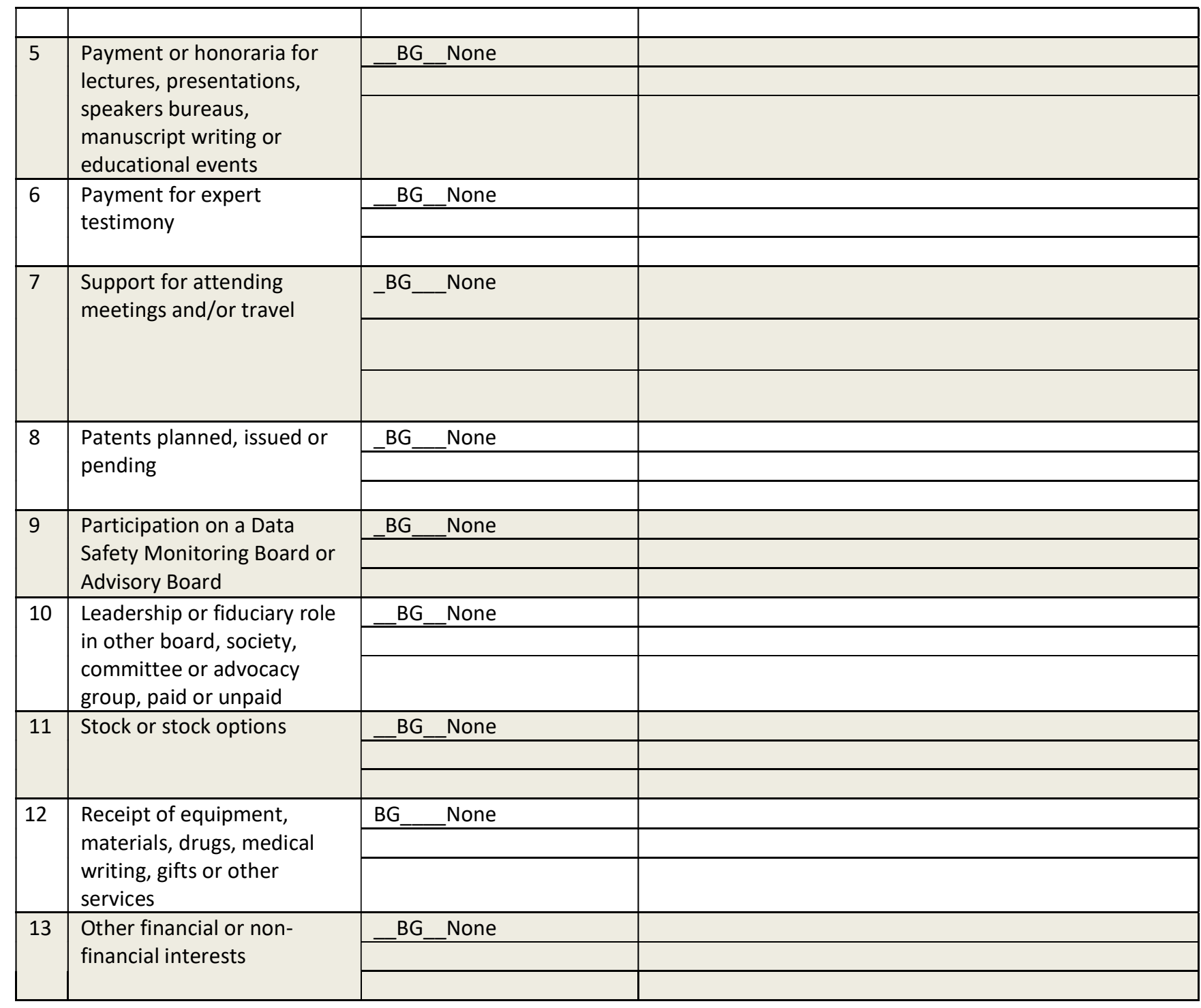

Please place an " $X$ " next to the following statement to indicate your agreement:

X_ I certify that I have answered every question and have not altered the wording of any of the questions on this form. 


\section{ICMJE DISCLOSURE FORM}

Date: $3 / 8 / 2021$

Your Name:

Christopher M. Bland

Manuscript Title: Less Common Bacterial, Fungal, and Viral Infections: Review of Management in the Pregnant Patient

Manuscript number (if known):

In the interest of transparency, we ask you to disclose all relationships/activities/interests listed below that are related to the content of your manuscript. "Related" means any relation with for-profit or not-for-profit third parties whose interests may be affected by the content of the manuscript. Disclosure represents a commitment to transparency and does not necessarily indicate a bias. If you are in doubt about whether to list a relationship/activity/interest, it is preferable that you do so.

The following questions apply to the author's relationships/activities/interests as they relate to the current manuscript only.

The author's relationships/activities/interests should be defined broadly. For example, if your manuscript pertains to the epidemiology of hypertension, you should declare all relationships with manufacturers of antihypertensive medication, even if that medication is not mentioned in the manuscript.

In item \#1 below, report all support for the work reported in this manuscript without time limit. For all other items, the time frame for disclosure is the past $\mathbf{3 6}$ months.

\begin{tabular}{|c|c|c|c|}
\hline & & $\begin{array}{l}\text { Name all entities with } \\
\text { whom you have this } \\
\text { relationship or indicate } \\
\text { none (add rows as } \\
\text { needed) }\end{array}$ & $\begin{array}{l}\text { Specifications/Comments } \\
\text { (e.g., if payments were made to you or to your } \\
\text { institution) }\end{array}$ \\
\hline & & \multicolumn{2}{|c|}{ Time frame: Since the initial planning of the work } \\
\hline \multirow[t]{6}{*}{1} & \multirow{6}{*}{$\begin{array}{l}\text { All support for the present } \\
\text { manuscript (e.g., funding, } \\
\text { provision of study materials, } \\
\text { medical writing, article } \\
\text { processing charges, etc.) } \\
\text { No time limit for this item. }\end{array}$} & $\mathrm{X}$ _ None & \\
\hline & & & \\
\hline & & & \\
\hline & & & \\
\hline & & & \\
\hline & & & \\
\hline & & Time frame: $p$ & 36 months \\
\hline \multirow[t]{3}{*}{2} & \multirow{3}{*}{$\begin{array}{l}\text { Grants or contracts from } \\
\text { any entity (if not indicated } \\
\text { in item \#1 above). }\end{array}$} & None & Merck (Grant Funding made to institution) \\
\hline & & & ALK Abello (Grant Funding made to institution) \\
\hline & & & \\
\hline 3 & Royalties or licenses & X_None & \\
\hline 4 & Consulting fees & None & Merck: Payments made to me \\
\hline
\end{tabular}




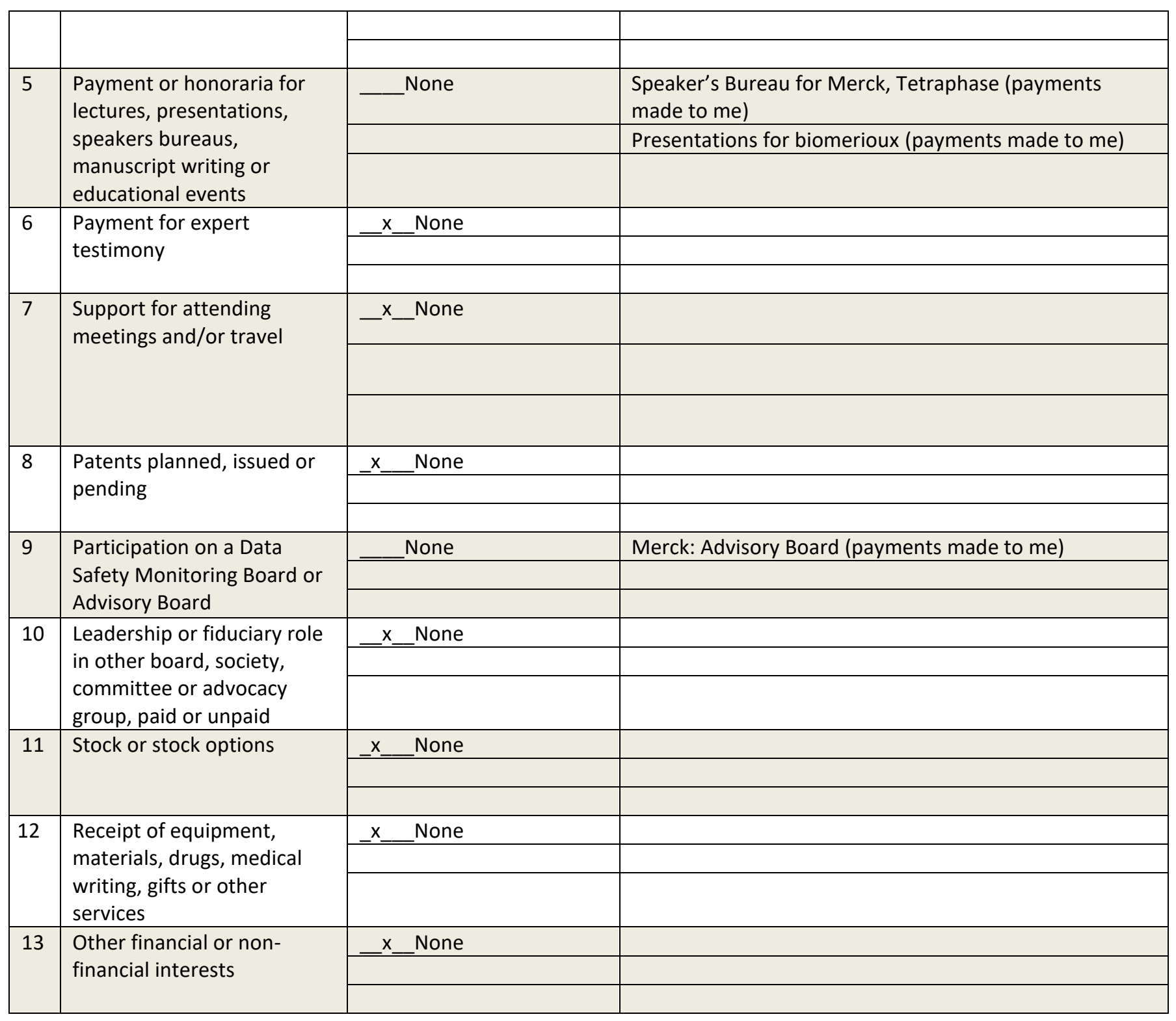

Please place an " $X$ " next to the following statement to indicate your agreement:

_. $\mathrm{x}$ _ I certify that I have answered every question and have not altered the wording of any of the questions on this form. 


\section{ICMJE DISCLOSURE FORM}

Date:_3/8/2021

Your Name:__Lea Eiland

Manuscript Title: Less Common Bacterial, Fungal, and Viral Infections: Review of Management in the Pregnant Patient

Manuscript number (if known):

In the interest of transparency, we ask you to disclose all relationships/activities/interests listed below that are related to the content of your manuscript. "Related" means any relation with for-profit or not-for-profit third parties whose interests may be affected by the content of the manuscript. Disclosure represents a commitment to transparency and does not necessarily indicate a bias. If you are in doubt about whether to list a relationship/activity/interest, it is preferable that you do so.

The following questions apply to the author's relationships/activities/interests as they relate to the current manuscript only.

The author's relationships/activities/interests should be defined broadly. For example, if your manuscript pertains to the epidemiology of hypertension, you should declare all relationships with manufacturers of antihypertensive medication, even if that medication is not mentioned in the manuscript.

In item \#1 below, report all support for the work reported in this manuscript without time limit. For all other items, the time frame for disclosure is the past $\mathbf{3 6}$ months.

\begin{tabular}{|c|c|c|c|}
\hline & & $\begin{array}{l}\text { Name all entities with } \\
\text { whom you have this } \\
\text { relationship or indicate } \\
\text { none (add rows as } \\
\text { needed) }\end{array}$ & $\begin{array}{l}\text { Specifications/Comments } \\
\text { (e.g., if payments were made to you or to your } \\
\text { institution) }\end{array}$ \\
\hline \multicolumn{4}{|c|}{ Time frame: Since the initial planning of the work } \\
\hline \multirow[t]{7}{*}{1} & \multirow{7}{*}{$\begin{array}{l}\text { All support for the present } \\
\text { manuscript (e.g., funding, } \\
\text { provision of study materials, } \\
\text { medical writing, article } \\
\text { processing charges, etc.) } \\
\text { No time limit for this item. }\end{array}$} & X_None & \\
\hline & & & \\
\hline & & & \\
\hline & & & \\
\hline & & & \\
\hline & & & \\
\hline & & & \\
\hline & & Time frame: $p$ & 36 months \\
\hline \multirow[t]{3}{*}{2} & \multirow{3}{*}{$\begin{array}{l}\text { Grants or contracts from } \\
\text { any entity (if not indicated } \\
\text { in item \#1 above). }\end{array}$} & $\mathrm{X}$ _ None & \\
\hline & & & \\
\hline & & & \\
\hline 3 & Royalties or licenses & _ X__ None & \\
\hline \multirow[t]{2}{*}{4} & \multirow[t]{2}{*}{ Consulting fees } & $\mathrm{X} \quad$ None & \\
\hline & & & \\
\hline
\end{tabular}




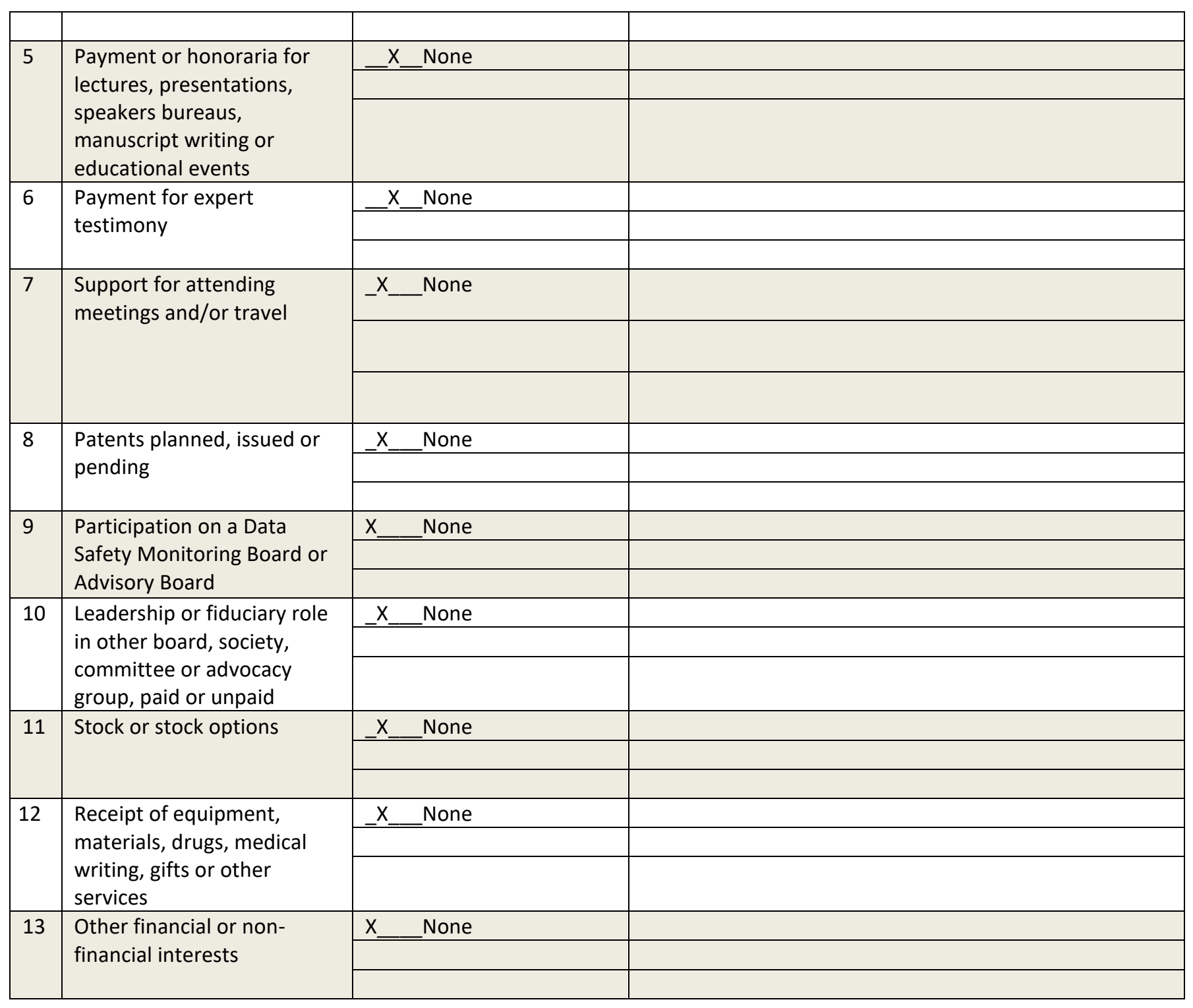

Please place an " $X$ " next to the following statement to indicate your agreement:

_ $\mathrm{X}$ _ I certify that I have answered every question and have not altered the wording of any of the questions on this form. 


\section{ICMJE DISCLOSURE FORM}

Date:_3/8/2021

Your Name:_Milena Murray

Manuscript Title: Less Common Bacterial, Fungal, and Viral Infections: Review of Management in the Pregnant Patient

Manuscript number (if known):

In the interest of transparency, we ask you to disclose all relationships/activities/interests listed below that are related to the content of your manuscript. "Related" means any relation with for-profit or not-for-profit third parties whose interests may be affected by the content of the manuscript. Disclosure represents a commitment to transparency and does not necessarily indicate a bias. If you are in doubt about whether to list a relationship/activity/interest, it is preferable that you do so.

The following questions apply to the author's relationships/activities/interests as they relate to the current manuscript only.

The author's relationships/activities/interests should be defined broadly. For example, if your manuscript pertains to the epidemiology of hypertension, you should declare all relationships with manufacturers of antihypertensive medication, even if that medication is not mentioned in the manuscript.

In item \#1 below, report all support for the work reported in this manuscript without time limit. For all other items, the time frame for disclosure is the past $\mathbf{3 6}$ months.

\begin{tabular}{|c|c|c|c|}
\hline & & $\begin{array}{l}\text { Name all entities with } \\
\text { whom you have this } \\
\text { relationship or indicate } \\
\text { none (add rows as } \\
\text { needed) }\end{array}$ & $\begin{array}{l}\text { Specifications/Comments } \\
\text { (e.g., if payments were made to you or to your } \\
\text { institution) }\end{array}$ \\
\hline \multicolumn{4}{|c|}{ Time frame: Since the initial planning of the work } \\
\hline \multirow[t]{7}{*}{$\overline{1}$} & \multirow{7}{*}{$\begin{array}{l}\text { All support for the present } \\
\text { manuscript (e.g., funding, } \\
\text { provision of study materials, } \\
\text { medical writing, article } \\
\text { processing charges, etc.) } \\
\text { No time limit for this item. }\end{array}$} & _ & \\
\hline & & & \\
\hline & & & \\
\hline & & & \\
\hline & & & \\
\hline & & & \\
\hline & & & \\
\hline \multirow{3}{*}{2} & & Time frame: $p$ & 36 months \\
\hline & \multirow{2}{*}{$\begin{array}{l}\text { Grants or contracts from } \\
\text { any entity (if not indicated } \\
\text { in item \#1 above). }\end{array}$} & $\mathrm{x}$ _None & \\
\hline & & & \\
\hline \multirow[t]{2}{*}{3} & \multirow[t]{2}{*}{ Royalties or licenses } & X_ None & \\
\hline & & & \\
\hline \multirow[t]{2}{*}{4} & \multirow[t]{2}{*}{ Consulting fees } & $x$ None & \\
\hline & & & \\
\hline
\end{tabular}




\begin{tabular}{|c|c|c|c|}
\hline \multirow[t]{3}{*}{5} & \multirow{3}{*}{$\begin{array}{l}\text { Payment or honoraria for } \\
\text { lectures, presentations, } \\
\text { speakers bureaus, } \\
\text { manuscript writing or } \\
\text { educational events }\end{array}$} & None & Speaker's bureau for Merck \& Co. \\
\hline & & & FreeCE.com, paid presenter \\
\hline & & & \\
\hline \multirow[t]{2}{*}{6} & \multirow{2}{*}{$\begin{array}{l}\text { Payment for expert } \\
\text { testimony }\end{array}$} & . $x$ _None & \\
\hline & & & \\
\hline \multirow[t]{2}{*}{7} & \multirow{2}{*}{$\begin{array}{l}\text { Support for attending } \\
\text { meetings and/or travel }\end{array}$} & - & \\
\hline & & & \\
\hline \multirow[t]{2}{*}{8} & \multirow{2}{*}{$\begin{array}{l}\text { Patents planned, issued or } \\
\text { pending }\end{array}$} & _ & \\
\hline & & & \\
\hline \multirow[t]{2}{*}{9} & \multirow{2}{*}{$\begin{array}{l}\text { Participation on a Data } \\
\text { Safety Monitoring Board or } \\
\text { Advisory Board }\end{array}$} & None & Theratechnologies \\
\hline & & & \\
\hline \multirow[t]{3}{*}{10} & \multirow{3}{*}{$\begin{array}{l}\text { Leadership or fiduciary role } \\
\text { in other board, society, } \\
\text { committee or advocacy } \\
\text { group, paid or unpaid }\end{array}$} & None & AAHIVM, Board of Directors, unpaid \\
\hline & & & ICHP, Board of Directors, unpaid \\
\hline & & & \\
\hline \multirow[t]{2}{*}{11} & \multirow[t]{2}{*}{ Stock or stock options } & _. None & \\
\hline & & & \\
\hline \multirow[t]{3}{*}{12} & \multirow{3}{*}{$\begin{array}{l}\text { Receipt of equipment, } \\
\text { materials, drugs, medical } \\
\text { writing, gifts or other } \\
\text { services }\end{array}$} & $x$ None & \\
\hline & & & \\
\hline & & & \\
\hline \multirow[t]{2}{*}{13} & \multirow{2}{*}{$\begin{array}{l}\text { Other financial or non- } \\
\text { financial interests }\end{array}$} & _. None & \\
\hline & & & \\
\hline
\end{tabular}

Please place an " $X$ " next to the following statement to indicate your agreement:

_. _ I I certify that I have answered every question and have not altered the wording of any of the questions on this form. 